\title{
Swath Mapping on the Continental SHELF AND Slope: The Eel River Basin, NORTHERN CALIFORNIA
}

\section{. . morphological \\ structure of surficial \\ features at a level of \\ detail and coverage \\ unavailable by any}

other means.
By John A. Goff, Larry A. Mayer, John Hughes-Clarke and Lincoln F. Pratson

$\mathrm{T}$ HE STRATAFORM program sponsored by the Office of Naval Research (Nittrouer and Kravitz. 1996. this issue) seeks to understand how sedimentary processes lead to the formation of the stratigraphic sequences on continental margins. A central challenge facing this effort is to understand the transport of sediments in shore-parallel as well as shore-perpendicular directions. Multidimensionality is necessary to describe, for example, the accumulation of sediments from river inputs. the distribution of gullies and canyons on the slope, the meandering of channels, and the structure of slumps and slides.

Acoustic swath mapping, which produces rapid, detailed, and complete aerial coverage of seabed bathymetry and backscatter, is a key component to investigating the multidimensionality of the continental-margin environment. Swath bathymetry provides data on the morphological structure of surficial features at a level of detail and coverage unavailable by any other means. Sidescan backscatter is responsive to both the composition and fine-scale roughness of surface sediments. Such information is complementary to other data sources, such as cores and seismic-reflection profiles that provide constraints on seafloor types and subseafloor structure. Collectively, these data will supply observational constraints for understanding and ultimately predicting sedimentary processes and strata formation on the shelf and slope within the STRATAFORM study areas.

The STRATAFORM program includes swathmapping field work in two natural laboratories: the Eel River margin of northern California (Fig. 1),

John A. Goff, University of Texas Institute for Geophysics, 8701 N. MoPac Expressway, Austin, TX 78759, USA; Larry A. Mayer and John Hughes-Clarke, Ocean Mapping Group. Department of Geodesy \& Geomatics Engineering, University of New Brunswick. Fredericton, N.B., E3B 5A3, Canada; Lincoln F. Pratson, Institute of Arctic and Alpine Research. University of Colorado, Boulder, CO 80309 . USA. and the New Jersey margin (Austin et al., 1996. this issue). The Eel margin was mapped using the Simrad EM1000 system in the summer of 1995 aboard the R/V Pacific Hunter. The New Jersey margin Was mapped with the same system in the summer of 1996 aboard the Canadian Hydrographic Services vessel F.G. Creed. The EM1000 operates at $95 \mathrm{kHz}$ (both bathymetry and sidescan), with bathymetric resolution generally better than $\sim 50 \mathrm{~cm}$. The New Jersey slope was previously mapped with the deeper-water, coarser-resolution Sea Beam system (Pratson et al., 1994). These data abut the newly collected New Jersey EM1000 survey, and the combined data set will provide continuous coverage from $\sim 20 \mathrm{~m}$ to $\sim 2.500 \mathrm{~m}$ depth. The objective of this report is to examine the morphological data from the continental shelf and slope of the Eel margin and, in particular, its relevance to sedimentary transport processes operating in this area.

\section{Geological Setting}

The Eel margin is part of a larger active continental margin influenced both by the eastward subduction of the Gorda plate beneath North America and by the northward migration of the Mendocino Triple Junction (e.g., Clarke, 1987). The Little Salmon fault and anticline (Fig. 1) run NW-SE through the survey area and constitute an important tectonic and structural boundary in the subsurface. The Eel River (Fig. 1) is the primary source of sediments deposited within the survey area (e.g., Wheatcroft et al, 1996, this issue), although there is also a significant contribution from the Mad River (Fig. 1). Figure 2 displays the sidescan and bathymetry data collected using the EM1000 during the Eel margin survey. Below we discuss the primary observations derived from this data set.

\section{Shelf Morphology}

The continental shelf of the Eel River Basin (depths less than $\sim 120 \mathrm{~m}$ ) is topographically very smooth (Fig. 2). What small-scale morphology does exist (ripples, bioturbation, etc.) is below the resolu- 


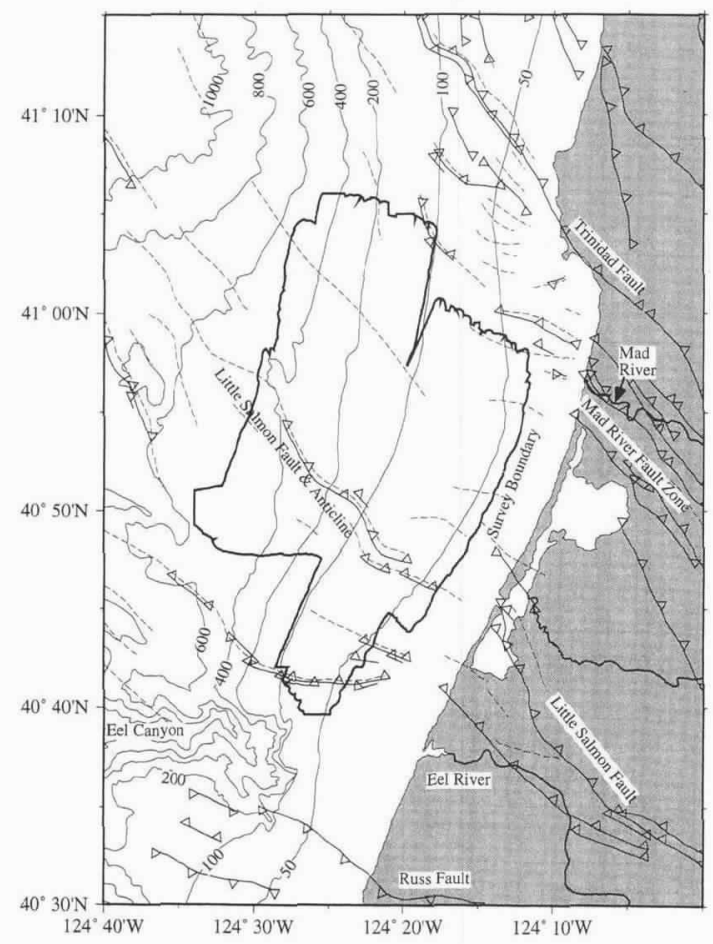

Fig. 1: Location of the Eel River Basin swathmapping survey (bold lines). Bathymetric contours in meters. Thrust faults (triangles on upthrown block) and anticline axes (dashed lines) are digitized from Clarke (1987).

tion of the Simrad EM1000 instrument. The smoothness of the shelf is likely due to large input of fine terrigenous sediments from the Eel and Mad rivers and reworking by storms. The only bathymetric features on the shelf notable in Figure 2 are the shallows associated with the Eel River and Mad River sediment bulges and a dredge-spoil dump site.

The bathymetry of the shelf is not, however, entirely devoid of character. Subtle, longer-wavelength structures do exist but are difficult to see because they are small compared with the overall gradient of the shelf. Figure 3 displays contours of residual bathymetry on the shelf, where a regional shelf gradient has been subtracted from the bathymetry (see caption for details). Here the most dominating structures evident are the Eel River sediment bulge and an elongated secondary bulge that extends $>20 \mathrm{~km}$ northward from the primary bulge, between $\sim 55 \mathrm{~m}$ and $90 \mathrm{~m}$ water depth (Fig. 2) with $\sim 1-6 \mathrm{~m}$ of relief. The location and strike of the secondary bulge correlates with the southern half of the flood deposit (see thickness contours overlain on Fig. 3) mapped by Wheatcroft et al. (1996, this issue) from coring work conducted in February, 1995. This observation suggests a possible connection between a long-term effect (the secondary bulge) and a short-term process (floods). Freshly deposited sediments are subject to resuspension and redistribution through physi- cal and biological processes, so it is possible that flood deposits may not be retained and the correlation could be mere coincidence. However, in a study of earlier Eel River floods (Borgeld, 1996), it was found that a significant portion of sediments deposited during large (decadal scale) floods are usually preserved in the stratigraphic record for water depths $>60 \mathrm{~m}$. We therefore infer that the secondary Eel River sediment bulge is likely formed by enhanced long-term deposition on the shelf associated with repeated Eel River floods.

The southern side of the Mad River sediment bulge also exhibits an elongated secondary bulge. Unlike the Eel River secondary bulge described above, this one extends to the south $\sim 8 \mathrm{~km}$ from the Mad River sediment bulge (Fig. 3) and lies between $\sim 40$ and $60 \mathrm{~m}$ water depth. It is unlikely that this secondary bulge can be attributed to flood deposits: studies indicate that sediment transport during flood events is generally northward (Wheatcroft et al., 1996, this issue). One possibility is that this feature may be a remnant of when the Mad River mouth was $\sim 4 \mathrm{~km}$ south of its current position, $\sim 30$ y ago (J. Borgeld, personal communication). Near the northern limit of the Eel River secondary bulge there exists a marked steepening to seaward, forming an indentation into the shelf (Fig. 3). This observation is discussed below.

Unlike the bathymetry, the sidescan image of the shallow $(<70 \mathrm{~m})$ shelf is quite varied over short length scales. Most noticeable are the low backscatter sandy deposits of the Eel River and Mad River sediment bulges. In the absence of strong local slope variations, backscatter intensity responds to bottom roughness and subbottom heterogeneity at scales less than the acoustic wavelength ( 1.6 cm for EM1000). Bottom photographs and samples (Wiberg et al., 1996, this issue) indicate that muddy bottoms and subbottoms are roughened at such scales by bioturbation. We therefore speculate that bioturbation may be an important factor in making muddy deposits acoustically brighter to the EM1000 acoustic wavelength than sandy deposits. More intriguing, however, are a series of subtle shore-normal striations $\sim 0.2$ to 1 $\mathrm{km}$ wide that appear to emanate northward from the Eel River sediment bulge (Fig. 2). These generally lie between $\sim 50$ and $\sim 70 \mathrm{~m}$ depth, taper off from south to north, and disappear just south of the Mad River sediment bulge. They have no discernible topographic expression but lie along the shoreward side of the secondary Eel bulge noted above and in Figure 3. We therefore speculate that these striations are associated in some way with northward transport of Eel River sediments.

\section{Slope Morphology}

The southern part of the continental slope within the survey area is dominated by the Humboldt slide (Fig. 2) (Field and Barber, 1993), a
. . a possible

connection between

a long-term effect

(the secondary bulge)

and a short-term

process (floods). 


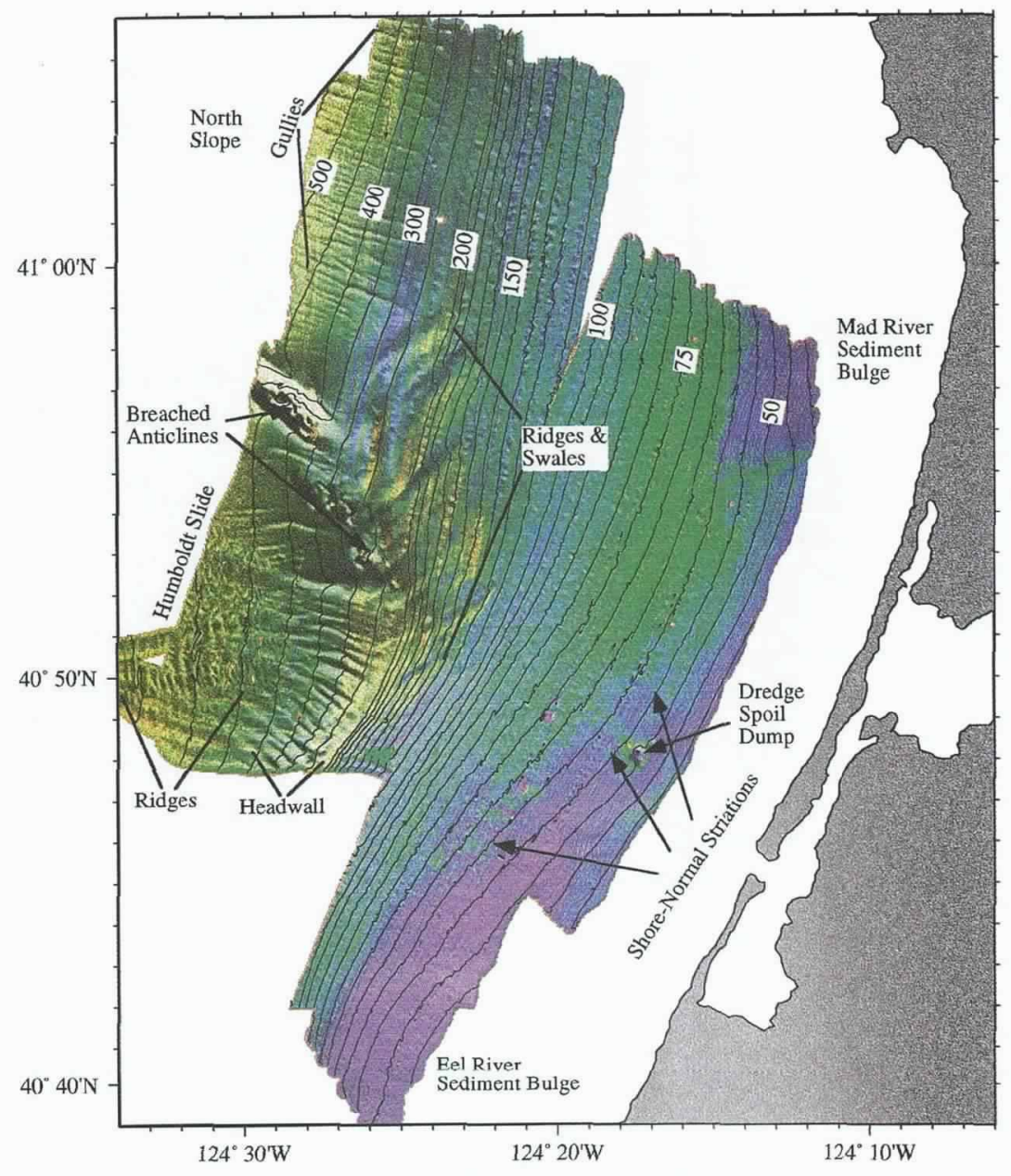

Fig. 2: Gridded sidescan and bathymetry data from the Eel River Basin swath-mapping survey. Colors are derived from side-scan backscatter data, with warmer colors (red and yellow) indicating high backscatter, and cooler colors (blue and purple) indicating low backscatter. Shading is derived from artificial sun illumination of bathymetry (azimuth $N 25^{\circ} \mathrm{E}$ ). Contours are in meters. Principal features discussed in the text are identified.

. . . at the outlet of

several ... of the

headwall gullies there

is a small fan-like

structure.
1996, this issue; Austin et al., 1996, this issue), is interpreted to be outcrop of subsurface strata and evidence for erosion. The shallowest part of this high backscatter region extends to the shelf indentation noted in Figure 3.

Figure 4 displays a detailed view of the morphology for part of the Humboldt slide headwall and its base. Changes in the contour pattern from pointing upslope to downslope and a downslope-expanding crenulated pattern indicate that at the outlet of several (but not all) of the headwall gullies there is a small fan-like structure. The Humboldt slide

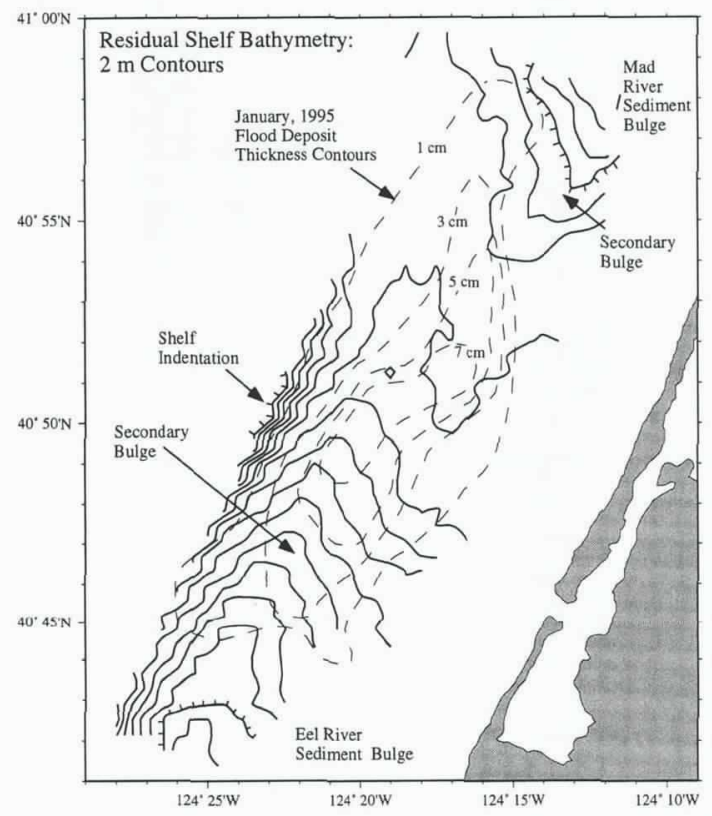

Fig. 3: Residual shelf bathymetry (depths $<100$ $m)$, indicated with solid contours (2-m contour interval). Formulating residual bathymetry involved the following steps. 1) To prevent shore curvature from creating false anomalies, 18 shore-parallel profiles, from $\sim 40$ to $100 \mathrm{~m}$ depth, were sampled from the gridded data set. 2) Over most profiles, the minimum depth sampled along the profile was subtracted from the profile. This value, rather than the mean, was subtracted because the major anomalies on the shelf, the Eel and Mad River sediment bulges, are positive. 3) Over the deepest four profiles there is an evident large negative anomaly, so in these cases the depth subtracted was chosen from a location toward the northern end of the survey, where the outer shelf appears to be devoid of "anomalous" character. 4) The detrended profiles, sampled in geographical coordinates, were gridded and contoured at 2- $m$ intervals. Overlain in thin dashed contours are measurements of flood-deposit thickness measured in February, 1995 (Wheatcroft et al., 1996, this issue). The southern half of the flood deposit correlates with a secondary bulge emanating northward from the Eel River sediment bulge. 
ridges lie downslope of the fan structures; there is no obvious connection between the two evident in the seafloor morphology, although a connection cannot be ruled out. We infer that the fan structures contain sediments that have deposited at the base of the headwall after flowing through the gullies, probably as turbidity flows, and that the previously noted high backscatter region (Fig. 2) and shelf indentation (Fig. 3) above the headwall are a source of these sediments. We suggest that turbidity flows have been a significant factor in the evolution of the headwall morphology.

Two breached anticlines (Clarke, 1987) bound the northern side of the Humboldt slide (Fig. 2). North and east of these lies a series of sinuous ridges and swales oriented roughly perpendicular to the breached anticlines (Fig. 2). The amplitude of these structures decreases from west $(\sim 20 \mathrm{~m})$ to east $(\sim 1 \mathrm{~m})$, and cross contours at $\sim 45^{\circ}$. The ridges and swales are strongly correlated with changes in acoustic backscatter in the sidescan data: the seaward slopes exhibit high backscatter and the landward slopes exhibit low backscatter. Proximity to the breached anticlines suggests a causal relationship, but interpretation of these features must await analysis of high-resolution seismic-reflection data.

A series of seaward-trending linear slope gullies occurs along the north slope (Figs. 2 and 5). The shelf break here is $\sim 60 \mathrm{~m}$ deeper and $\sim 7 \mathrm{~km}$ farther from shore than the shelf break in the Humboldt slide region. The gullies on the north slope are an order of magnitude smaller $(\sim 2 \mathrm{~m})$ than those incising the headwall of the Humboldt slide, although both sets have similar spacing $(\sim 100-1,000 \mathrm{~m})$. The former are generally confined to depths greater than $\sim 300 \mathrm{~m}$, a depth that also marks the steepest part of this shelf terrace. In comparison, the Humboldt slide gullies rise to depths as shallow as $180 \mathrm{~m}$.

Gullies similar to those on the north slope have been observed on the New Jersey continental slope between submarine canyons within the east coast STRATAFORM study area (Pratson et al., 1994). However, the upslope termini of northern California gullies do not abruptly end in failure headwalls as on the New Jersey continental slope. Instead, they rise gradually to the elevation of the surrounding seafloor. Other similar gullies have been observed on the Arguello slope, California by Reynolds and Gorsline (1988), who interpreted them as erosional in nature.

How the slope gullies formed on the north slope remains uncertain. Reynolds and Gorsline (1988) discuss numerous possibilities for gully formation, and we refer the reader to that reference for a full discussion. One that we favor is that the gullies have been formed by turbidity flows composed of sediments introduced from the Eel and Mad Rivers. This scenario has parallels to

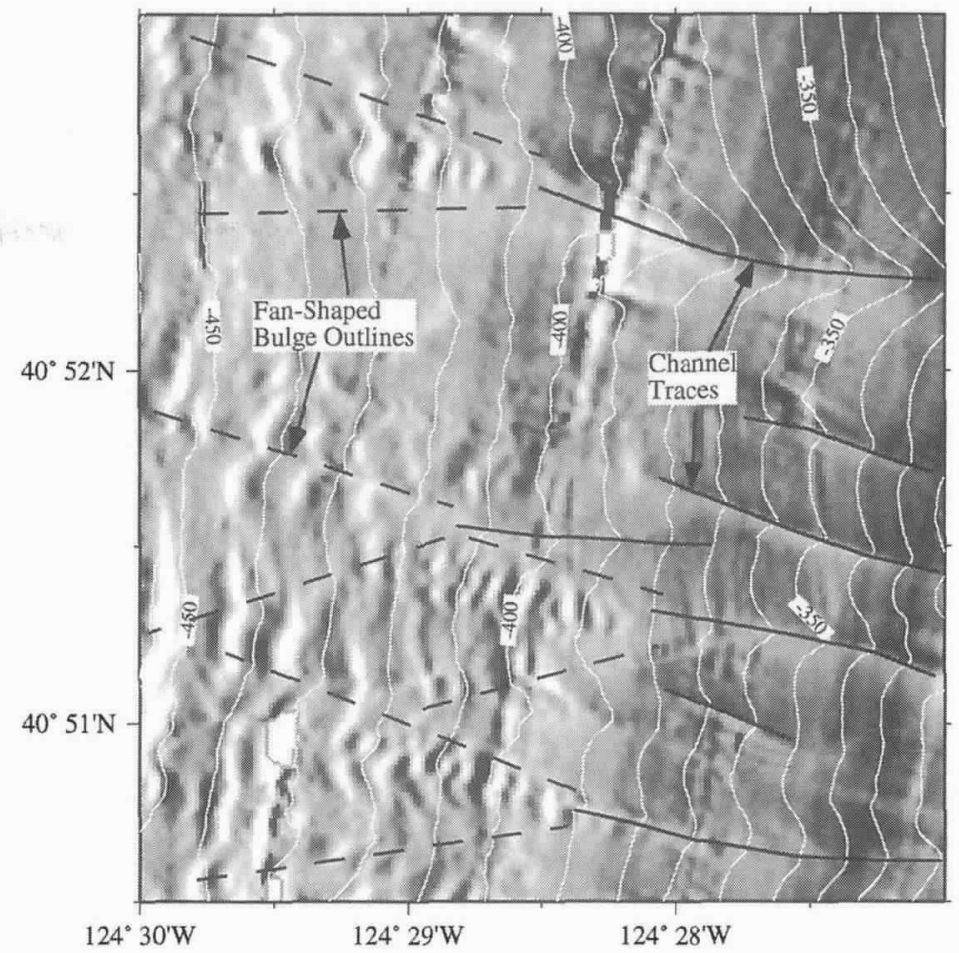

Fig. 4: Sun-illuminated image of the northern part of Humboldt slide headwall, with bathymetric contours in meters. Illumination is from the East. Image shows evidence of fan deposits (outlined, where present, with dashed lines) at the base of several channels (solid lines).

early stages of submarine canyon formation predicted by the seascape-evolution model of Pratson and Coakley (1996). Initiation of flow may be induced by several mechanisms, including sediment oversteepening, fluid or gas seepage, and seismic triggering. However, the lack of a headwall scarp and minimum depth limitation suggest that these gullies are not growing by headward erosion, as appears to be the case on the New Jersey shelf.

The north slope also contains numerous small circular depressions, generally less than $\sim 100 \mathrm{~m}$ in diameter (Fig. 5). Such features have been interpreted by others (e.g., Field and Barber, 1993) as craters formed by seeping gas. In the vicinity of the gullies, the depressions are often aligned within the gullies, especially at the northern limit of the survey. Elsewhere they appear randomly distributed. In the southern half of Figure 5, there are numerous gullies formed without any depressions in the vicinity. We conclude that gullies are affecting the position and formation of depressions, rather than vice versa.

\section{Future Directions}

One of the primary purposes of the swath-mapping work described here was to provide a geological and morphological context for the seismic, coring, sampling, and modeling investigations that are also part of STRATAFORM. In so doing we have raised many questions and generated many 


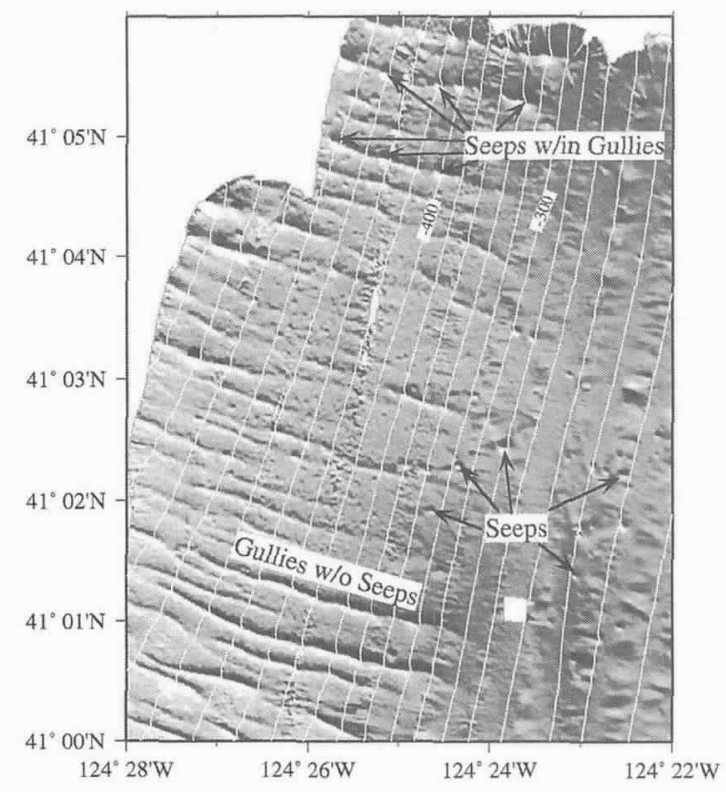

Fig. 5: Sun-illuminated image of the north slope region (Fig. 1), with bathymetric contours in meters. Illumination is from azimuth $N 20^{\circ} \mathrm{E}$. Image shows small gullies incising lower half of terrace slope, and the presence of small circular depressions, interpreted as gas seeps, many of which are aligned within the gullies.

... some of the

high-backscatter

anomalies are erosional

unconformities . . . and swales, and the gullies of the north slope and the Humboldt slide headwall.

\section{Acknowledgements}

This work was supported by the Office of Naval Research through grants N0014-95-1-0067 (J.A. Goff), N00014-95-1-0064 (L.A. Mayer), and N0014-93-1-0126 (L.F. Pratson). We thank Joe Kravitz, without whom STRATAFORM would not exist, and the captain and crew of the $R / \mathrm{VPa}$ cific Hunter and the personnel of C\&C Technologies for their assistance and support during the swath-mapping field program. Reviews by C. Nittrouer, B. Carson, and D. Swift led to substantial improvements on an earlier draft. We appreciate constructive discussions with J. Austin, J. Borgeld, M. Field, C. Fulthorpe, J. Gardner, H. Lee, B. McAdoo, G. Mountain, D. Orange, and J. Yun. This is UTIG Contribution 1232.

\section{References}

Austin, J.A., C.S. Fulthorpe, G.S. Mountain, D.L. Orange and M.E. Field, 1996: Continental-margin seismic stratigraphy: assessing the preservation potential of heterogeneous geologic processes operating on continental shelves and slopes. Oceanography, 9, 173-177.

Borgeld, J.C., 1996: Preservation potential of strata deposited on the Eel River shelf during 1986 and 1989 flooding of the Eel River. Eos Trans. AGU, 76, OS10.

Clarke, S.H., Jr., 1987: Geology of the California continental margin north of Cape Mendocino. In: Geology and Resource Potential of the Continental Margin of Western North America and Adjacent Ocean Basins-Beaufort Sea to Baja California. D.W. Scholl, A. Grantz and J.G. Vedder, eds. Circum-Pacific Council for Energy and Mineral Resources, Earth Science Series, vol. 6, 337-351

Field, M.E. and J.H. Barber, 1993: A submarine landslide associated with shallow sea-floor gas and gas hydrates off northern California. In: Submarine Landslides: Selected Studies in the U.S. Exclusive Economic Zone. W.C. Schwab, H.J. Lee and D.C. Twichell, eds. United States Geological Survey Bulletin 2002, 151-157.

Nittrouer, C.A. and J.H. Kravitz, 1996: STRATAFORM: a program to study the creation and interpretation of sedimentary strata on continental margins. Oceanography, 9, 146-152.

Pratson, L.F. and B.J. Coakley, 1996: A model for the headward erosion of submarine canyons induced by downslope eroding sediment flows. Geol. Soc. Am. Bull., 108, 225-234

pth. These issues will be addressed within STRATAFORM; systematic coring will provide information on surface sediment types and volumetric heterogeneity in the immediate subbottom, and microtopography analysis will provide information on bottom roughness.

Seismic-reflection data, as we have already discussed, are also critical to our understanding of the features identified in the swath-map data. Although bathymetry and sidescan data provide exquisite detail and complete aerial coverage, seismic reflection penetrates into the internal architecture of features, which in many cases is essential to determine how they were formed. Features of particular interest to be investigated with seismic reflection include the Eel and Mad River primary and secondary sediment bulges, the Humboldt slide, the breached anticlines and nearby ridges
W.B.F. Ryan, G.S. Mountain and D.C. Twichell, 1994 : Submarine canyon initiation by downslope-eroding sediment flows: evidence in late Cenozoic strata on the New Jersey continental slope. Geol. Soc. Am. Bull., $106,395-412$. sions of the Arguello slope, California. Geo-Mar. Lett., $8,167-172$

Syvitski, J.P., C.R. Alexander, M.E. Field, J.V. Gardner, D.L. Orange and J.W. Yun, 1996: Continental-slope sedimentation: the view from northern California. Oceanography, 9, 163-167.

Wheatcroft, R.A., J.C. Borgeld, R.S. Born, D.E. Drake, E.L. Leithold, C.A. Nittrouer and C.K. Sommerfield, 1996: The anatomy of an oceanic flood deposit. Oceanogra-

Wiberg, P.L., D.A. Cacchione, R.W. Sternberg and L.D. Wright, 1996: Linking sediment transport and stratigraphy on the continental shelf. Oceanography, 9, 153-157.
Reynolds, S. and D.S. Gorsline, 1988: Some enigmatic depresphy, 9, 158-162. 